\title{
Association between in vivo bone formation and ex vivo migratory capacity of human bone marrow stromal cells
}

Rikke K. Andersen ${ }^{1 \dagger}$, Walid Zaher ${ }^{1,2 \dagger}$, Kenneth H. Larsen ${ }^{1}$, Nicholas Ditzel ${ }^{1}$, Katharina Drews ${ }^{3}$, Wasco Wruck ${ }^{4}$, James Adjaye ${ }^{3,4}$, Basem M. Abdallah ${ }^{1,5^{*}}$ and Moustapha Kassem ${ }^{1,2,6}$

\begin{abstract}
Introduction: There is a clinical need for developing systemic transplantation protocols for use of human skeletal stem cells (also known bone marrow stromal stem cells) (hBMSC) in tissue regeneration. In systemic transplantation studies, only a limited number of hBMSC home to injured tissues suggesting that only a subpopulation of hBMSC possesses "homing" capacity. Thus, we tested the hypothesis that a subpopulation of hBMSC defined by ability to form heterotopic bone in vivo, is capable of homing to injured bone.

Methods: We tested ex vivo and in vivo homing capacity of a number of clonal cell populations derived from telomerized hBMSC (hBMSC-TERT) with variable ability to form heterotopic bone when implanted subcutaneously in immune deficient mice. In vitro transwell migration assay was used and the in vivo homing ability of transplanted hBMSC to bone fractures in mice was visualized by bioluminescence imaging (BLI). In order to identify the molecular phenotype associated with enhanced migration, we carried out comparative DNA microarray analysis of gene expression of hBMSC-derived high bone forming (HBF) clones versus low bone forming (LBF) clones.

Results: HBF clones were exhibited higher ex vivo transwell migration and following intravenous injection, better in vivo homing ability to bone fracture when compared to LBF clones. Comparative microarray analysis of HBF versus LBF clones identified enrichment of gene categories of chemo-attraction, adhesion and migration associated genes. Among these, platelet-derived growth factor receptor (PDGFR) $a$ and $\beta$ were highly expressed in HBF clones. Follow up studies showed that the chemoattractant effects of PDGF in vitro was more enhanced in HBF compared to LBF clones and this effect was reduced in presence of a PDGFRß-specific inhibitor: SU-16 f. Also, PDGF exerted greater chemoattractant effect on PDGFR $\beta^{+}$cells sorted from LBF clones compared to PDGFR $\beta^{-}$cells.
\end{abstract}

Conclusion: Our data demonstrate phenotypic and molecular association between in vivo bone forming ability and migratory capacity of hBMSC. PDGFRß can be used as a potential marker for the prospective selection of hBMSC populations with high migration and bone formation capacities suitable for clinical trials for enhancing bone regeneration.

\footnotetext{
* Correspondence: babdallah@health.sdu.dk

${ }^{\dagger}$ Equal contributors

'Department of Endocrinology and Metabolism, University Hospital of

Odense, Odense, Denmark

${ }^{5}$ Faculty of Science, Helwan University, Cairo, Egypt

Full list of author information is available at the end of the article
}

C Biomed Central (c) 2015 Andersen et al. Open Access This article is distributed under the terms of the Creative Commons Attribution 4.0 International License (http://creativecommons.org/licenses/by/4.0/), which permits unrestricted use, distribution, and reproduction in any medium, provided you give appropriate credit to the original author(s) and the source, provide a link to the Creative Commons license, and indicate if changes were made. The Creative Commons Public Domain Dedication waiver (http://creativecommons.org/publicdomain/zero/1.0/) applies to the data made available in this article, unless otherwise stated. 


\section{Introduction}

Human skeletal stem cells (also known as human bone marrow-derived stromal cells (hBMSC)) are adult multipotent stem cells located in the bone marrow perivascular niche and are recruited to bone formation sites during bone remodeling [1]. During recent years, hBMSC have been tested in a number of clinical trials for their ability to enhance tissue repair including tissue regeneration where hBMSC were injected locally at the sites of tissue injury; for example, bone fracture [2-4] or ischemic myocardium [5-8]. However, systemic intravenous infusion is more suitable for clinical cell transplantation and is employed for hematopoietic stem cell (HSC) transplantation with success and where HSCs, following homing from systemic circulation to bone marrow, engraft and initiate hematopoiesis [9].

Several studies have demonstrated that systemically injected bone marrow-derived stromal cells (BMSC) can home to damaged tissues in animal models of brain injury [10], skeletal disorders [11-13], and acute radiation syndrome $[14,15]$. However, the number of BMSC that home and engraft in injured tissues is usually small and most of the infused BMSC get entrapped in the lungs $[16,17]$. The explanation for these phenomena is still missing because the mechanisms governing migration of BMSC to injured tissues are poorly understood [18].

Cultured hBMSC are a heterogeneous population of cells that when analyzed at a clonal level exhibit variations in cell morphology, proliferation, and differentiation capacity $[19,20]$. Recently, we have also demonstrated that clonal heterogeneity of the hBMSC population reflects functional heterogeneity with respect to cell capacity for osteoblast adipocyte differentiation or immune functions $[21,22]$.

Here we hypothesized the existence of clonal heterogeneity in the ability of hBMSC to home to injured tissues (e.g., bone fractures) and that hBMSC with good bone-forming capacity will be more efficient at homing to bone fracture sites. To test this hypothesis, we examined the ex vivo and in vivo migratory capacity of a number of clonal cell populations isolated from telomerized hBMSC that exhibit variation in their ability to form heterotopic bone when implanted in vivo [21]. Our results demonstrate that there is phenotypic association between the in vivo bone formation and migratory capacity to bone fracture sites, and furthermore identified platelet-derived growth factor receptor (PDGFR) $\alpha$ and PDGFR $\beta$ as potential markers for the hBMSC population with enhanced migratory function.

\section{Methods}

Human mesenchymal stem cell culture

As a model for primary hBMSC, we employed our well-characterized telomerized hBMSC-TERT cell line, established by ectopic expression of the catalytic subunit of human telomerase as described previously [23]. The hBMSC-TERT cells exhibit a stable cellular and molecular phenotype during in vitro culture similar to that of primary hBMSC [24]. The derivation and characterization of hBMSC-TERT $^{+ \text {Bone }}$, hBMSC-TERT ${ }^{- \text {Bone }}$, and high boneforming (HBF) and low bone-forming (LBF) single-cell clones have been described previously by our group [21]. In brief, the hBMSC-TERT ${ }^{+B o n e}$ subpopulation was derived from early-passage hBMSC-TERT cells (population doubling level 77), and showed high capacity for in vivo heterotopic bone formation, while the hBMSC-TERT $^{- \text {Bone }}$ subpopulation was derived from hBMSC-TERT cells (population doubling level 233), and showed LBF capacity. Both the HBF and LBF single-cell clones were derived from hBMSC-TERT $^{+ \text {Bone }}$ cells by the limiting dilution method.

The cells were cultured in a standard growth medium containing minimal essential medium (MEM) (Gibco, Invitrogen, Herlev, Denmark) supplemented with $10 \%$ fetal calf serum (FCS) (Biochrom, Berlin, Germany) and $1 \%$ penicillin/streptomycin (Gibco, Invitrogen, Herlev, Denmark) at $37^{\circ} \mathrm{C}$ in a humidified atmosphere containing $5 \% \mathrm{CO}_{2}$. The medium was changed every third day until cells became $90 \%$ confluent.

\section{Studying cell spreading and focal adhesion formations}

Cell culture plates were coated with fibronectin $(10 \mu \mathrm{g} / \mathrm{ml})$ in phosphate-buffered saline (PBS) for 2 hours at $37{ }^{\circ} \mathrm{C}$, rinsed twice with PBS, and blocked with $1 \%$ bovine serum albumin (BSA) for 1 hour. Cells were trypsinized, washed twice with MEM, and resuspended in serum-free medium for 1 hour at room temperature. Cell were then replated onto fibronectin-coated plates in standard culture medium supplemented with platelet-derived growth factor (PDGF)-BB $(100 \mathrm{ng} / \mathrm{ml})$ for 30 minutes at $37{ }^{\circ} \mathrm{C}$. Cells were fixed in $4 \%$ paraformaldehyde for 10 minutes, washed with PBS, and stained for F-actin with Phalloidinfluorescein isothiocyanate (FITC) (Sigma, Brøndby, Denmark) and for focal adhesion with mouse monoclonal anti-Vinculin antibody (Sigma, Brøndby, Denmark) using Alexa Fluor ${ }^{\circ}$ 488-conjugated rabbit anti-mouse IgG $(\mathrm{H}+\mathrm{L})$ as secondary antibody (Cell Signaling). Fluorescent staining was visualized by the Operetta ${ }^{\circ}$ High Content Imaging system (Perkin Elmer, Rodgau, Germany) at $20 \times$ magnification. Fluorescent images were analyzed using Harmony ${ }^{\circ}$ High Content Imaging Analysis Software (Perkin Elmer, Rodgau, Germany).

\section{Microarray analysis}

Microarray analysis was performed on hBMSC-TERT ${ }^{+ \text {Bone }}$, hBMSC-TERT $^{-B o n e}$, and hBMSC-TERT-derived singlecell clones: HBF (three clones; DD8, AD10, BB10) and LBF (three clones; CF1, CB4, CB8). To perform global gene expression analysis, $500 \mathrm{ng}$ quality-checked total 
RNA per sample in triplicate were amplified and labeled according to the manufacturer's protocol (Illumina TotalPrep RNA Amplification Kit; Ambion, Austin, TX, USA [25]). The resulting biotinylated cRNA was purified and hybridized to Illumina HumanRef-8 v3 Expression BeadChips (Illumina, San Diego, CA, USA [26]) on the Illumina Beadstation 500 platform. This was followed by washing, blocking, staining with streptavidin- $\mathrm{Cy} 3$, and quantitative detection of the fluorescent image of the array as specified by the manufacturer.

Raw data were processed using the Gene Expression Module version 1.8.0 provided with the GenomeStudio software (Illumina). This included background subtraction and normalization according to the "rank invariant" algorithm. Genes were considered "expressed" if the corresponding "Detection P-Value" given by the GenomeStudio software was $p_{\text {det }}<0.01$. Differential gene expression analysis was computed using the Illumina Custom Model. $p$ values of differentially expressed genes ("Diff P-Values") were modified by the Benjamini and Hochberg false discovery rate (FDR) correction algorithm [27]. Genes were considered differentially expressed genes if: they exhibited twofold upregulation or downregulation in average signal intensity; the corresponding FDR-adjusted "Diff P-Value" was $p_{\text {adj }}<0.05$; or the gene of interest was expressed in at least one of the samples under consideration.

Differentially upregulated genes in group 1 (hBMSCTERT $^{+B o n e}$ and three HBF clones) when compared with group 2 (hBMSC-TERT ${ }^{- \text {Bone }}$ and three LBF clones) are presented in Table 1.

Functional annotation and identification of enriched biological categories were carried out using DAVID platform version 6.7 [28-30].

The microarray data have been deposited in the public repository [GEO:GSE69358].

\section{Total RNA isolation and real-time PCR}

RNA was isolated from cultured cells using Trizol ${ }^{\circ}$ (BioRad, Herlev, Denmark) according to the manufacturer's protocol. cDNA was synthesized using a commercial revertAid $\mathrm{H}$ minus first strand cDNA synthesis kit (Fermentas, Copenhagen, Denmark) according to the instruction manual. Real-time PCR was performed in the iCycler IQ detection system (Bio-Rad, Herlev, Denmark) using SYBR $^{\circ}$ Green I as described previously [24]. Primer sequences are indicated in Table S1 in Additional file 1. The expression level for each target gene was calculated using the comparative $\mathrm{Ct}$ formula $1 /\left(2^{\Delta \mathrm{Ct}}\right)$ and data were presented as relative expression to the reference genes (RG) (HPRT1 and UBC). Data were analyzed using Microsoft Excel 2000 to generate relative expression values.

\section{Flow cytometry analysis}

Cells were trypsinized and washed with PBS containing $0.5 \%$ BSA (Fluorescence Activated Cell Sorting (FACS) buffer) and $50 \mu \mathrm{g} / \mathrm{ml}$ trypsin inhibitor. Cells were then incubated with primary antibody for PDGFR $\beta$ (0.025 mg/ml, PR292a; R\&D Systems (Abingdon, UK) diluted 1:50 in FACS buffer for 30 minutes on ice. The cells were washed twice with ice-cold FACS buffer and incubated with FITC-conjugated goat anti-mouse antibody (R\&D Systems) for 30 minutes on ice. The cells were analyzed by flow cytometer Cell Lab Quanta TMSC (Beckman Coulter using Kaluza version1.2 (Beckman Coulter, Copenhagen, Denmark).

\section{Magnetic activated cell sorting of hBMSC-TERT ${ }^{-B o n e}$}

Cells were rinsed with PBS, lifted with trypsin, and diluted in Magnetic activated cell sorting (MACS) buffer (PBS with $0.5 \%(\mathrm{w} / \mathrm{v}) \mathrm{BSA}$ and $2 \mathrm{mM}$ ethylenediamine tetraacetic acid (EDTA)) before incubation with PDGFR $\beta$ antibody (R\&D Systems) for 20 minutes at $4^{\circ}$ C. Cells were washed with MACS buffer, incubated with anti-mouse-beads (Miltenyi Biotec, Lund, Sweden) for 15 minutes at $4{ }^{\circ} \mathrm{C}$, and run through a MS column (Miltenyi Biotec, Lund, Sweden) according to the manufacturer's instructions.

\section{Generating the Luciferase-overexpressing hBMSC-TERT +Bone and hBMSC-TERT ${ }^{-B o n e}$}

The hBMSC-TERT ${ }^{+ \text {Bone }}$ and hBMSC-TERT ${ }^{- \text {Bone cells }}$ were transduced with a retroviral vector containing the firefly luciferase gene (Luc2) producing luciferasecontaining hBMSC-TERT (hBMSC-TERT-Luc). The luciferase reporter gene luc2 (Photinus pyralis) was subcloned into the retroviral vector pBABE-puro (addgene Plasmid 1764). Retroviral vector was transfected into the PhoenixAMPHO packaging cells (CRL-3213 ${ }^{\text {mim }}$; ATCC), and cultured in Dulbecco's modified Eagle's medium (DMEM) medium (Gibco, Invitrogen, Herlev, Denmark) supplemented with $10 \%$ FCS until 70-80 \% confluent, using the FuGENE 6 (Roche, Hvidovre, Denmark) reagent according to the manufacturer's instruction. For cell transduction, the supernatants collected from Phoenix packaging cells containing virus particles were filtered with a $0.45 \mu \mathrm{m}$ filter and added to hBMSC-TERT cell lines in the presence of Polybrene (Sigma, Brøndby, Denmark). Stably transduced cells were selected on the antibiotic puromycine.

\section{In vitro differentiation studies and cytochemical staining Osteoblast differentiation}

Cells were plated at $2 \times 10^{4}$ cells $/ \mathrm{cm}^{2}$ in six-well plates in modified Dulbecco medium (MEM) (GIBCO, Herlev, Denmark) containing $10 \%$ fetal bovine serum (FBS) (GIBCO), $100 \mathrm{U} / \mathrm{ml}$ penicillin (GIBCO), and $100 \mu \mathrm{g} / \mathrm{ml}$ streptomycin (GIBCO). One day after plating, media 
Table 1 Genes differentially upregulated in HBF clones + hBMSC-TERT ${ }^{+ \text {Bone }}$ versus LBF clones + hBMSC-TERT ${ }^{-B o n e}$

\begin{tabular}{|c|c|c|c|c|c|c|}
\hline Category & PROBE_ID & $\begin{array}{l}\text { Gene } \\
\text { symbol }\end{array}$ & Gene name & $\begin{array}{l}\text { Fold } \\
\text { change }\end{array}$ & $p$ value & Gene function \\
\hline \multirow[t]{15}{*}{ Migration } & ILMN_1798360 & CXCR7 & $\begin{array}{l}\text { Chemokine (C-X-C motif) } \\
\text { receptor } 7\end{array}$ & 30.34323 & $1.57 \times 10^{-5}$ & Receptor for CXCL12/SDF1 \\
\hline & ILMN_1689111 & CXCL12 & $\begin{array}{l}\text { Chemokine (C-X-C motif) } \\
\text { ligand } 12\end{array}$ & 7.64381 & $6.57 \times 10^{-5}$ & $\begin{array}{l}\text { Activates the C-X-C chemokine receptor CXCR4 to } \\
\text { induce a rapid and transient rise in the level of } \\
\text { intracellular calcium ions and chemotaxis }\end{array}$ \\
\hline & ILMN_2373791 & ENPP2 & $\begin{array}{l}\text { Ectonucleotide } \\
\text { pyrophosphatase/ } \\
\text { phosphodiesterase 2 }\end{array}$ & 6.481839 & $1.58 \times 10^{-13}$ & Leukocyte-endothelial cell adhesion \\
\hline & ILMN_1722713 & FBLN1 & Fibulin 1 & 5.060076 & $8.1 \times 10^{-17}$ & Plays a role in cell adhesion and migration \\
\hline & ILMN_2082585 & SNAI2 & Snail homolog 2 & 4.84552 & $3.28 \times 10^{-25}$ & $\begin{array}{l}\text { Involved in the generation and migration of } \\
\text { neural crest cells }\end{array}$ \\
\hline & ILMN_1811313 & SLIT3 & Slit homolog 3 & 4.378596 & $1.14 \times 10^{-15}$ & $\begin{array}{l}\text { Acts as molecular guidance cue in cellular } \\
\text { migration }\end{array}$ \\
\hline & ILMN_1802646 & EPHB6 & $\mathrm{EPH}$ receptor $\mathrm{B} 6$ & 4.171862 & 0.00022 & Modulates cell adhesion and migration \\
\hline & ILMN_2086470 & PDGFRA & $\begin{array}{l}\text { Platelet-derived growth factor } \\
\text { receptor, alpha polypeptide }\end{array}$ & 4.168592 & 0.009945 & Receptor that binds both PDGFA and PDGFB \\
\hline & ILMN_2339266 & LAMA2 & Laminin, alpha 2 & 3.959818 & $5.47 \times 10^{-6}$ & $\begin{array}{l}\text { Mediates the attachment, migration, and } \\
\text { organization of cells into tissues during embryonic } \\
\text { development }\end{array}$ \\
\hline & ILMN_2307903 & VCAM1 & $\begin{array}{l}\text { Vascular cell adhesion } \\
\text { molecule } 1\end{array}$ & 3.080952 & $7.75 \times 10^{-5}$ & Plays a role in leukocyte endothelial cell adhesion \\
\hline & ILMN_1757338 & PLSCR4 & Phospholipid scramblase 4 & 2.885336 & 0.008172 & $\begin{array}{l}\text { Mediates bidirectional transbilayer migration of } \\
\text { phospholipids, plays a central role in the initiation } \\
\text { of fibrin clot formation and activation of mast } \\
\text { cells and in the recognition of apoptotic and } \\
\text { injured cells }\end{array}$ \\
\hline & ILMN_1761540 & SEMA3F & $\begin{array}{l}\text { Sema domain, } \\
\text { immunoglobulin domain }(\mathrm{lg}) \text {, } \\
\text { short basic domain, secreted, } \\
\text { (semaphorin) } 3 \mathrm{~F}\end{array}$ & 2.657031 & $8.68 \times 10^{-8}$ & Plays a role in cell motility and cell adhesion \\
\hline & ILMN_1659306 & SVIL & Supervillin & 2.569266 & 0.001237 & $\begin{array}{l}\text { May modulate myosin II regulation through MLCK } \\
\text { during cell spreading, an initial step in cell } \\
\text { migration }\end{array}$ \\
\hline & ILMN_1667893 & TNS3 & Tensin 3 & 2.446932 & $5.1 \times 10^{-6}$ & Involved in cell migration and bone development \\
\hline & ILMN_1815057 & PDGFRB & $\begin{array}{l}\text { Platelet-derived growth factor } \\
\text { receptor }\end{array}$ & 2.147921 & $5.33 \times 10^{-10}$ & Receptor that binds both PDGF-AA and PDGF-BB \\
\hline \multirow[t]{7}{*}{ Adhesion } & ILMN_2408683 & PPAP2B & $\begin{array}{l}\text { Phosphatidic acid phosphatase } \\
\text { type } 2 B\end{array}$ & 8.923443 & $4.45 \times 10^{-11}$ & $\begin{array}{l}\text { May be involved in cell adhesion and in cell-cell } \\
\text { interactions }\end{array}$ \\
\hline & ILMN_1684554 & COL16A1 & Collagen, type XVI, alpha 1 & 3.998721 & $4.96 \times 10^{-12}$ & $\begin{array}{l}\text { Involved in mediating cell attachment and } \\
\text { induction of integrin-mediated cellular reactions, } \\
\text { such as cell spreading and alterations in cell } \\
\text { morphology }\end{array}$ \\
\hline & ILMN_1801246 & IFITM1 & $\begin{array}{l}\text { Interferon induced } \\
\text { transmembrane protein } 1 \text { (9-27) }\end{array}$ & 3.467308 & $1.36 \times 10^{-14}$ & $\begin{array}{l}\text { Component of a complex involved in adhesion } \\
\text { signals }\end{array}$ \\
\hline & ILMN_2396444 & CD14 & CD14 molecule & 3.169754 & 0.000265 & $\begin{array}{l}\text { Upregulates cell surface molecules, including } \\
\text { adhesion molecules }\end{array}$ \\
\hline & ILMN_2307903 & VCAM1 & $\begin{array}{l}\text { Vascular cell adhesion } \\
\text { molecule } 1\end{array}$ & 3.080952 & $7.75 \times 10^{-5}$ & Plays a role in leukocyte endothelial cell adhesion \\
\hline & ILMN_2229877 & PCDH18 & Protocadherin 18 & 2.939445 & $6.56 \times 10^{-8}$ & Potential calcium-dependent cell-adhesion protein \\
\hline & ILMN_1761540 & SEMA3F & Sema domain, & 2.657031 & $8.68 \times 10^{-8}$ & May play a role in cell motility and cell adhesion \\
\hline
\end{tabular}


Table 1 Genes differentially upregulated in HBF clones + hBMSC-TERT ${ }^{+ \text {Bone }}$ versus LBF clones + hBMSC-TERT ${ }^{-B o n e}$ (Continued)

\begin{tabular}{|c|c|c|c|c|c|c|}
\hline & ILMN_1812461 & WISP2 & $\begin{array}{l}\text { WNT1 inducible signaling } \\
\text { pathway protein } 2\end{array}$ & 2.336378 & 0.001181 & $\begin{array}{l}\text { Promotes the adhesion of osteoblast cells and } \\
\text { inhibits the binding of fibrinogen to integrin } \\
\text { receptors }\end{array}$ \\
\hline & ILMN_1769575 & JAM3 & Junctional adhesion molecule 3 & 2.195171 & $4.39 \times 10^{-5}$ & May participate in cell-cell adhesion \\
\hline & ILMN_2223941 & FBLN5 & Fibulin 5 & 2.099419 & 0.000119 & $\begin{array}{l}\text { Promotes adhesion of endothelial cells through } \\
\text { interaction of integrins }\end{array}$ \\
\hline & ILMN_2115125 & CTGF & $\begin{array}{l}\text { Connective tissue growth } \\
\text { factor }\end{array}$ & 2.037551 & $3 \times 10^{-9}$ & $\begin{array}{l}\text { Mediates heparin-dependent and divalent } \\
\text { cation-dependent cell adhesion }\end{array}$ \\
\hline & ILMN_1707070 & PCOLCE & $\begin{array}{l}\text { Procollagen C-endopeptidase } \\
\text { enhancer }\end{array}$ & 2.023961 & $1.28 \times 10^{-5}$ & Procollagen C-endopeptidase enhancer \\
\hline \multirow{9}{*}{$\begin{array}{l}\text { Bone } \\
\text { formation }\end{array}$} & ILMN_1696391 & LEPR & Leptin receptor & 9.88173 & 0.000244 & Leptin receptor \\
\hline & ILMN_1690945 & $C P Z$ & Carboxypeptidase Z & 6.636527 & $2.46 \times 10^{-11}$ & Modulates the Wnt signaling pathway \\
\hline & ILMN_1800317 & WNT5A & $\begin{array}{l}\text { Wingless-type MMTV } \\
\text { integration site family, } \\
\text { member } 5 \mathrm{~A}\end{array}$ & 4.39779 & $5.65 \times 10^{-6}$ & Can activate or inhibit canonical Wnt signaling \\
\hline & ILMN_1709734 & BMP4 & Bone morphogenetic protein 4 & 3.425185 & 0.003465 & Induces cartilage and bone formation \\
\hline & ILMN_1758895 & CTSK & Cathepsin K (CTSK), mRNA. & 2.655974 & 0.000136 & Closely involved in osteoclastic bone resorption \\
\hline & ILMN_1684755 & KAZALD1 & $\begin{array}{l}\text { Kazal-type serine peptidase } \\
\text { inhibitor domain } 1\end{array}$ & 2.583283 & 0.001055 & $\begin{array}{l}\text { Involved in the proliferation of osteoblasts during } \\
\text { bone formation and bone regeneration }\end{array}$ \\
\hline & ILMN_1724480 & AXIN2 & Axin 2 & 2.432503 & $5.5 \times 10^{-7}$ & Downregulates beta-catenin \\
\hline & ILMN_1770161 & BST1 & $\begin{array}{l}\text { Bone marrow stromal cell } \\
\text { antigen } 1\end{array}$ & 2.417137 & 0.002254 & Involved in osteoclastic bone resorption \\
\hline & ILMN_1729368 & FZD8 & Frizzled homolog 8 & 2.013491 & 0.005335 & Receptor for Wnt proteins \\
\hline \multirow[t]{7}{*}{ Cytoskeletal } & ILMN_1812031 & PALM & Paralemmin & 9.661952 & 0.004851 & Control of cell shape \\
\hline & ILMN_1780334 & KCNJ2 & $\begin{array}{l}\text { Potassium inwardly-rectifying } \\
\text { channel, subfamily J, member } 2\end{array}$ & 9.409812 & $1.23 \times 10^{-21}$ & $\begin{array}{l}\text { Participates in establishing action potential } \\
\text { waveform and excitability of neuronal and muscle } \\
\text { tissues }\end{array}$ \\
\hline & ILMN_1654319 & HAPLN3 & $\begin{array}{l}\text { Hyaluronan and proteoglycan } \\
\text { link protein } 3\end{array}$ & 6.178261 & $3.95 \times 10^{-27}$ & \multirow[t]{2}{*}{ May function in hyaluronic acid binding } \\
\hline & ILMN_1741695 & COL12A1 & Collagen, type XII, alpha 1 & 2.071144 & 0.008916 & \\
\hline & ILMN_1670899 & FBN2 & Fibrillin 2 & 2.065329 & 0.000762 & $\begin{array}{l}\text { Contains microfibrils that regulate the early } \\
\text { process of elastic fiber assembly }\end{array}$ \\
\hline & ILMN_1674620 & SGCE & Sarcoglycan, epsilon & 2.034948 & $7.35 \times 10^{-6}$ & $\begin{array}{l}\text { A subcomplex of the dystrophin-glycoprotein } \\
\text { complex which forms a link between the F-actin } \\
\text { cytoskeleton and the extracellular matrix }\end{array}$ \\
\hline & ILMN_1780334 & KCNJ2 & $\begin{array}{l}\text { Potassium inwardly-rectifying } \\
\text { channel, subfamily J, member } \\
2\end{array}$ & 9.409812 & $1.23 \times 10^{-21}$ & $\begin{array}{l}\text { Participates in establishing action potential } \\
\text { waveform and excitability of neuronal and muscle } \\
\text { tissues }\end{array}$ \\
\hline
\end{tabular}

HBF high bone forming, $h B M S C$ human bone marrow-derived stromal cells, LBF low bone forming, PDGF platelet-derived growth factor

were replaced with osteogenic media including culture media supplemented with $10 \mathrm{mM} \beta$-glycerophosphate (Sigma, Brøndby, Denmark), $10 \mathrm{nM}$ dexamethasone (Sigma, Brøndby, Denmark), $10 \mathrm{nM}$ Calcitriol (1,25dihydroxyvitamin D3; Leo, Ballerup, Denmark), and $50 \mu \mathrm{g} / \mathrm{ml}$ vitamin C (Sigma, Brøndby, Denmark). The osteogenic medium was changed every other day for 2 weeks.

\section{Adipocyte differentiation}

For adipocyte differentiation, cells were plated at $3 \times 10^{4}$ cells $/ \mathrm{cm}^{2}$ in six-well plates in culture media. The day after, culture media was removed and adipogenic media was added including MEM (GIBCO), 10 \% FBS (GIBCO), $10 \%$ horse serum (GIBCO), $100 \mathrm{U} / \mathrm{ml}$ penicillin (GIBCO), $100 \mu \mathrm{g} / \mathrm{ml}$ streptomycin (GIBCO), $100 \mathrm{nM}$ dexamethasone (Sigma, Brøndby, Denmark), $0.25 \mathrm{mM}$ 3-isobutyl-1-methylxanthine (IBMX, Gibco, Herlev, Denmark), $1 \mu \mathrm{M}$ BRL (Rosiglitazone; Sigma, Brøndby, Denmark), and $500 \mathrm{nM}$ insulin (Sigma, Brøndby, Denmark,). The adipogenic medium was changed every other day for 20 days.

\section{Alkaline phosphatase staining}

At 7 and 14 days during osteoblast differentiation, cells were fixed with acetone/citrate $(10 \mathrm{mM})$ buffer, $\mathrm{pH} 4.2$ 
(1.5:1), for 5 minutes at room temperature and stained with the $1: 1$ mixture of $0.2 \mathrm{mg} / \mathrm{ml}$ Napthol-AS-TR-phosphate (Sigma) and $1.3 \mathrm{mg} / \mathrm{ml}$ Fast Red TR solution (Sigma) in 0.1 M Tris buffer, $\mathrm{pH}$ 9.0, for 1 hour at room temperature.

\section{Alizarin Red staining}

Alizarin Red staining was performed on days 7 and 14 of osteoblast differentiation to assess matrix mineralization of osteoblastic cultures. Cells were fixed with $70 \%$ icecold ethanol for 1 hour at $-20{ }^{\circ} \mathrm{C}$, and stained with 40 mM Alizarin Red S (AR-S; Sigma, Brøndby, Denmark), $\mathrm{pH} 4.2$, for 10 minutes at room temperature. The amount of mineralized matrix (bound stain) was quantified by eluting the Alizarin Red stain, using 20-minute incubation of the cultures in $10 \%$ (w/vol) cetylpyridinium chloride solution. The absorbance of the eluted stain was measured at $570 \mathrm{~nm}$ using FLUOstar Omega multimode microplate reader (Leica, Ballerup, Denmark).

\section{Oil Red 0 staining}

Adipocytic cultures from days 10 and 20 were fixed with $4 \%$ paraformaldehyde for 10 minutes at room temperature, rinsed with $3 \%$ isopropanol solution, and stained with Oil Red O (Sigma, USA) solution for 1 hour at room temperature. Oil Red O solution consist of $25 \mathrm{mg}$ Oil Red $\mathrm{O}$ dye, $5 \mathrm{ml}$ of $60 \%$ isopropanol, and $3.35 \mathrm{ml}$ $\mathrm{H}_{2} \mathrm{O}$. The bound dye was eluted by $100 \%$ isopropanol and absorbance measured at $490 \mathrm{~nm}$ using FLUOstar Omega multimode microplate reader.

\section{Microscopy}

Images were taken using a Leica ${ }^{\bullet}$ DM4500B microscope equipped with a motorized stage (Märzhäuser Wetzlar GmbH, Wetzlar, Germany) and a Leica ${ }^{\circ}$ DFC300 FX camera. Images were acquired with the Surveyor ${ }^{\circledR}$ software (Objective Imaging, Leica, Ballerup, Denmark).

\section{Boyden chamber transwell migration assay}

For migration experiments, $90 \%$ confluent cells were starved for 24 hours in low-glucose Dulbecco's minimal essential medium (LG-DMEM; GIBCO, Herlev, Denmark) supplemented with $0.1 \%(w / v)$ BSA (Sigma, Brøndby, Denmark), harvested, and assayed using the AP48 Migration Assay system and $8 \mu \mathrm{m}$ pore size polycarbonate membranes (NeuroProbe, Inc., USA). Membranes were coated for 1 hour at $37{ }^{\circ} \mathrm{C}$ with $5 \mu \mathrm{g} / \mathrm{ml}$ fibronectin (human placenta; Sigma) and $10 \mu \mathrm{g} / \mathrm{ml}$ rat tail collagen type I (Sigma, Brøndby, Denmark) in migration media consisting of LGDMEM (GIBCO) supplemented with $0.2 \%$ FBS (GIBCO). hBMSC-TERT cells in LG-DMEM with $0.1 \%$ BSA (control medium) with or without pretreatment (see later) were added to the wells. Control media with or without PDGFs were added to the lower chamber. The assembled assay was incubated at $37^{\circ} \mathrm{C}$ for 4 hours. After removal of cells on the upper side of the membrane with a rubber scraper, cell migration through the membrane was quantitated by staining cells with the Hemacolor staining kit (Merck), and cells were counted from one picture/well taken at $10 \times$ magnification by a computer-assisted cell-counting program (Visiopharm, Hørsholm, Denmark). The following concentrations of factors were used: PDGF-BB (PeproTech GmbH Hamburg, Germany), 10-100 ng/ ml; PDGF-AA (PeproTech GmbH Hamburg, Germany), 100 ng/ml; PDGF-AB (PeproTech GmbH Hamburg, Germany), $100 \mathrm{ng} / \mathrm{ml}$; and PDGFR $\beta$ inhibitor (SU16f; Tocris), 10-200 nM. Then $1 \mu \mathrm{l} / \mathrm{ml}$ vehicle (dimethyl sulfoxide (DMSO)) were added to the cells just prior to assay assembly.

\section{In vivo homing studies Animals}

Ethical permission for animal study was granted from the Danish National Authority on animal experiments (2012-15-2934-00559). Immunodeficient NOD scid (NOD.CB17-Prkdc scid $/ J$ ) mice were used and operations were performed under intraperitoneal injection of ketamine (100 mg/kg) and xylazine $(10 \mathrm{mg} / \mathrm{kg})$. Temgesic $(100 \mathrm{mg} /$ $\mathrm{kg}$ ) was given subcutaneously every 8 hours to relieve postoperative pain for at least 3 days post procedure.

\section{Closed femur fracture}

The closed femur fracture procedure was carried out as described by Bonnarens and Einhorn [31]. In brief, an incision was made just medial to the patella, and then the longitudinal fibers of the quadriceps were divided and the patella dislocated laterally exposing the femur condyles. A $0.5 \mathrm{~mm}$ needle was inserted between the condyles and drilled in a retrograde fashion into the medullary cavity of the femur (functioning as a nail fixating the fracture). Afterwards, a standardized reproducible closed fracture was induced using a guillotine fracture apparatus [31]. A radiograph was acquired following fracture induction (using Faxitron MX-20; Faxitron XRay, Lincolnshire, USA) to confirm the fracture induction and needle position.

\section{Transplantation studies and bioluminescence imaging}

Immunodeficient NOD/SCID (NOD/LtSz/Prkdc ${ }^{\text {scid } / J) ~}$ 12 -week-old female mice $(n=24)$ were randomly divided into the two main fracture study groups. The hBMSCTERT $^{+ \text {Bone }}(n=12)$ or hBMSC-TERT ${ }^{- \text {Bone }}$ cells $(n=12)$ were injected intravenously via tail vein at a dose of $1 \times$ $10^{6}$ cells/mouse suspended in $200 \mu \mathrm{l}$ PBS per injection. For noninvasive imaging analysis, mice were injected with D-Luciferin $(150 \mathrm{mg} / \mathrm{kg}$, intraperitoneal injection; Caliber Life Sciences), and after 10 minutes the mice were placed in a supine position for image acquisition 
with 5 minutes of acquisition time using the IVIS Imaging System, 200 Series (Xenogen Corp., Rodgau, Germany). Bioluminescence color images were overlaid on gray-scale photographic images of the mice to allow for localization of the light source using the Livingimage ${ }^{\mathrm{TM}}$ software (V. 2.11) overlay (Xenogen Corp., Rodgau, Germany). To equalize comparisons across animals and between groups, the scales were fixed. Regions of interest (ROI) were manually selected, and signal intensity was expressed in terms of number of photons $/ \mathrm{cm}^{2} /$ second.

\section{Statistical analysis}

Data are presented as mean \pm standard error of the mean SEM. Statistical analysis was performed using unpaired, two-tailed Student's $t$ test for comparison between two groups and one-way analysis of variance for comparison between more than two groups using Graphpad Prism version 5.0 software (Graphpad Prism Software, Inc., La Jolla, CA, USA). For all experiments, $p<0.05$ compared with control was considered significant.

\section{Results}

hBMSC-TERT $^{+ \text {Bone }}$ cells demonstrate high ex vivo directed migratory function

To study whether the ability to form heterotopic bone in vivo is associated with an enhancement of the migratory capacity of hBMSC, we compared the ex vivo transwell migration ability of two populations derived from hBMSCTERT cells: one capable of in vivo bone formation (hBMSC-TERT ${ }^{+ \text {Bone}}$ ) versus one that lacks this ability (hBMSC-TERT $^{- \text {Bone) }}$ [21]. As shown in Fig. 1a, the transwell migration ability of hBMSC-TERT $^{+ \text {Bone }}$ toward

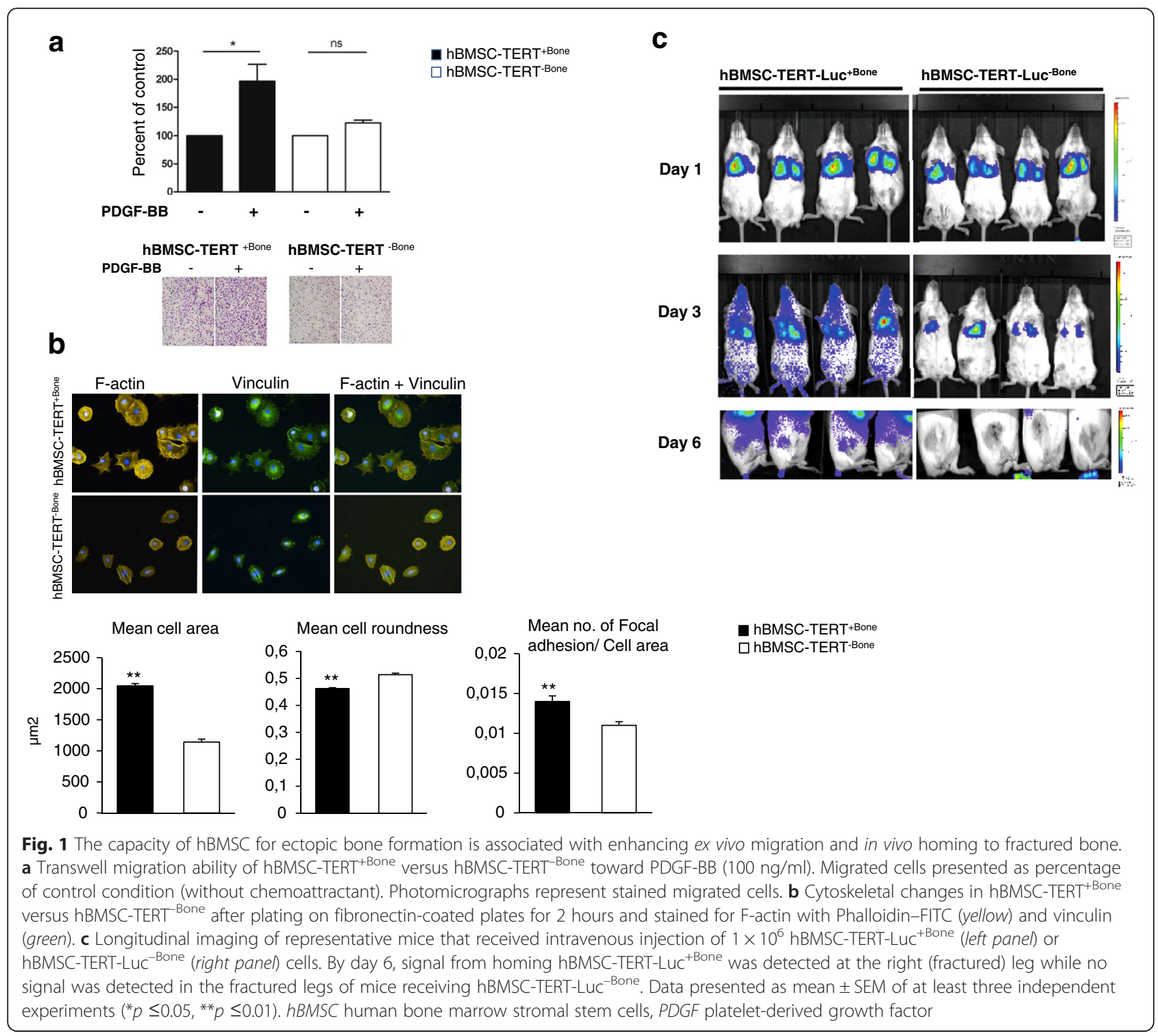


PDGF-BB was significantly higher compared with hBMSC-TERT ${ }^{-B o n e}$.

\section{hBMSC-TERT ${ }^{+ \text {Bone }}$ cells exhibit distinct cytoskeletal properties}

Since cell migration includes a cascade of cellular events of cell spreading and focal adhesion formation [32], we compared cytoskeletal and adhesion properties of hBMSC-TERT $^{+ \text {Bone }}$ versus hBMSC-TERT ${ }^{- \text {Bone }}$ when cultured on fibronectin-coated plates for 2 hours and stained for F-actin and vinculin. As shown in Fig. 1b, hBMSCTERT $^{+ \text {Bone }}$ exhibited more cells spreading with formation of cytoskeletal projections, increased mean cell area, and reduced mean cell roundness. In addition, the focal adhesion number per cell area, as visualized by vinculin staining, was increased in hBMSC-TERT ${ }^{+ \text {Bone }}$ (Fig. 1b).

\section{hBMSC-TERT ${ }^{+ \text {Bone }}$ cells exhibit enhanced in vivo homing to fractured bone site}

We further compared the in vivo homing ability of hBMSC-TERT $^{+ \text {Bone }}$ versus hBMSC-TERT $^{- \text {Bone }}$ to bone fracture sites in mice. hBMSC-TERT ${ }^{+ \text {Bone }}$ and hBMSCTERT $^{- \text {Bone }}$ were stably transduced with a retroviral vector expressing the luciferase gene 2 (Luc2). Luc-overexpressing cell lines exhibited high levels of luciferase enzyme activity and maintained their differentiation capacity similar to the parental cell lines (Figure S1a, b in Additional file 1). hBMSC-TERT-Luc ${ }^{+ \text {Bone }}$ and hBMSC-TERT-Luc ${ }^{- \text {Bone }}$ were administrated intravenously via tail vein injection in SCID/NOD mice with a stabilized femur bone fracture immediately following fracture induction. Noninvasive bioluminescence imaging using the IVIS Imaging System showed trapping of both cell lines in the lungs after 1 day (Fig. 1c). hBMSC-TERT ${ }^{+ \text {Bone }}$ cells and not hBMSCTERT $^{- \text {Bone }}$, were able to migrate to the fracture sites by day 6 (Fig. 1c).

\section{Molecular phenotype of hBMSC single-cell clones with enhanced migratory function}

Since hBMSC-TERT ${ }^{+ \text {Bone }}$ and hBMSC-TERT ${ }^{- \text {Bone }}$ are nonclonal populations, we further studied the migratory capacity of three hBMSC-TERT-derived single-cell clones with either HBF capacity (HBF1, HBF2, and HBF3) or three cell clones with LBF capacity (LBF1, LBF2, and LBF3) [21]. HBF clones showed higher migratory capacity toward PDGF-BB as compared with LBF clones, supporting our hypothesis of the existence of an association between the in vivo bone formation capacity and ex vivo migratory capacity of hBMSC (Fig. 2a).

To identify the molecular signature underlying enhanced hBMSC migratory function, we performed a global DNA microarray analysis comparing the transcriptome profile of hBMSC-TERT ${ }^{+ \text {Bone }}$, hBMSCTERT $^{- \text {Bone }}$, the three HBF clones (HBF1, HBF2, and
HBF3), and the three LBF clones (LBF1, LBF2, and LBF3). Cluster analysis revealed molecular clustering of HBF clones to hBMSC-TERT ${ }^{+ \text {Bone }}$ and LBF clones to hBMSC-TERT $^{- \text {Bone }}$ (Fig. 2b). We identified 427 genes (cutoff level $\geq 2$-fold, $p$ 0.05) that are upregulated in hBMSC-TERT ${ }^{+ \text {Bone }}$ and HBF clones compared with hBMSC-TERT $^{- \text {Bone }}$ and LBF clones (Table S2 in Additional file 1). Gene annotation analysis based on molecular functions revealed significant enrichment of gene categories of cell migration (12\%), cell adhesion (17\%), cytoskeletal genes (12\%), and bone-related genes (16\%) in hBMSC-TERT ${ }^{+ \text {Bone }}$ and HBF clones (Fig. 2c, Table 1). Some of the significantly upregulated genes by HBF clones were confirmed by real-time RT-PCR (Fig. 2d).

\section{PDGFRa and PDGFR $\beta$ are associated with enhanced hBMSC migration}

To identify surface marker(s) that can be used prospectively to isolate the hBMSC population with enhanced migratory functions, we examined differentially expressed genes in HBF clones. Both PDGFR $\alpha$ (CD140A) and PDGFR $\beta$ (CD140B) were found to be significantly upregulated by hBMSC-TERT ${ }^{+ \text {Bone }}$ and $\mathrm{HBF}$ clones versus hBMSC-TERT $^{-B o n e}$ and LBF clones by 4.16 -fold and 2.14-fold respectively (Table 1 ). These data have also been confirmed by quantitative RT-PCR analysis (Fig. 3a, b).

To test for the specific contribution of PDGFRs to migratory functions, we tested the effect of PDGF and other growth factors known to exert chemoattractant function: insulin-like growth factor 1 (IGF1), stromal cell-derived factor 1 (SDF1), and tumor necrosis factor alpha (TNF $\alpha)$. The ex vivo transwell migratory capacity of hBMSC-TERT ${ }^{+ \text {Bone }}$ was significantly higher toward PDGF-BB compared with other chemoattractants (Fig. 4a). We next confirmed the specificity of chemotactic effects of PDGF isoforms on hBMSC-TERT ${ }^{+ \text {Bone }}$. As shown in Fig. 4b, hBMSC-TERT ${ }^{+ \text {Bone }}$ exhibited higher migration toward heterodimeric PDGF-AB or homodimeric PDGF-AA and PDGF-BB proteins and their migration was decreased by adding the same concentration of PDGF isoform to both lower and upper chambers in the transwell migration assay (Fig. 4b). Furthermore, we demonstrated a dose-dependent stimulatory effect of PDGF-BB on increasing the migration of hBMSC-TERT $^{+ \text {Bone }}$ versus hBMSC-TERT ${ }^{- \text {Bone }}$ (Fig. 4c). In addition, selective inhibition of PDGFR $\beta$ signaling in hBMSC-TERT $^{+ \text {Bone }}$ using the chemical inhibitor SU-16f suppressed the migration of hBMSC-TERT ${ }^{+ \text {Bone }}$ toward PDGF-BB in a dose-dependent manner (Fig. 4d).

Identifying PDGFR $\beta$ as a marker for prospective isolation of a population of hBMSC with migratory function

To study the possible use of PDGFR $\beta$ as a candidate marker for isolating hBMSC with increased migratory 


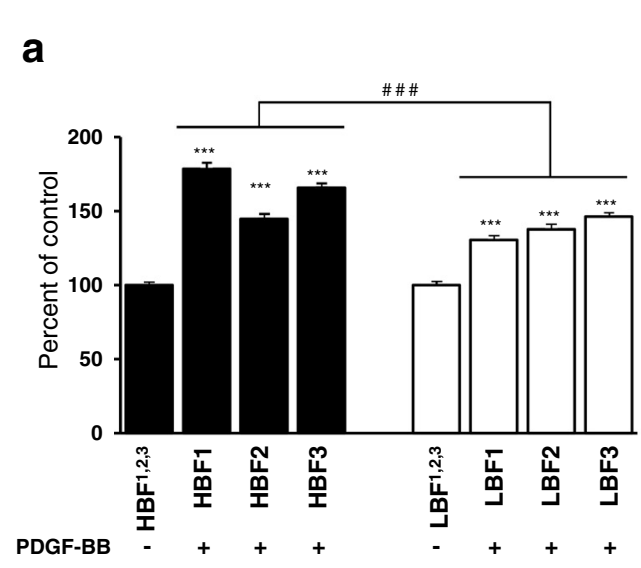

b

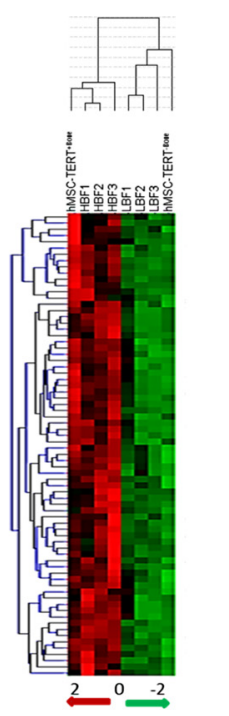

C

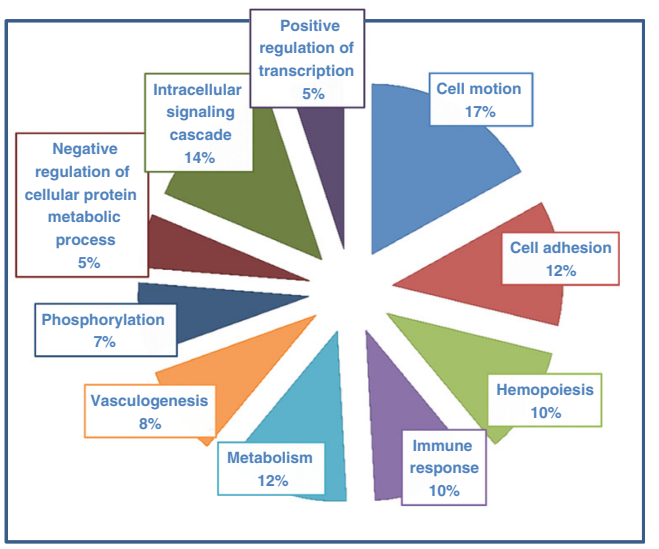

d
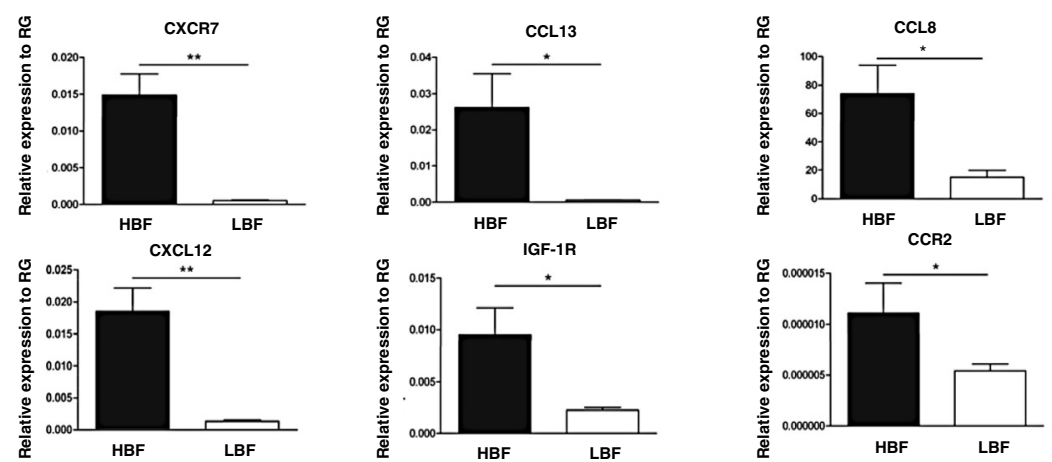

Fig. 2 Transcriptional upregulation of the migratory-related factors by hBMSC with high bone formation capacity. a The transwell migration ability of three high bone-forming (HBF1, HBF2, HBF3) clones versus three low bone-forming (LBF1, LBF2, LBF3) clones toward PDGF-BB (100 ng/ml). Migrated cells presented as percentage of control condition (without chemoattractant). Data presented as mean \pm SEM of at least three independent experiments per each clone ${ }^{* * *} p \leq 0.005$ as compared with nontreated control; \#\#\#p $\leq 0.005$ between the mean value of three HBF clones versus the mean value of three LBF clones). $\mathbf{b}$ Heat map of molecular signature of hBMSC-TERT ${ }^{\text {Bone, }}$ hBMSC-TERT ${ }^{\text {-Bone }}$, HBF clones (HBF1, HBF2, HBF3), and LBF clones (LBF1, LBF2, LBF3). Hierarchical clustering analysis based on Pearson's correlation (group gene profile, overall expression data) between different groups shows the clustering of HBF clones with hBMSC-TERT ${ }^{\text {Bone }}$ and LBF clones with hBMSC-TERT ${ }^{- \text {Bone }}$. $\mathbf{c}$ Annotation analysis of differentially upregulated genes ( $p<0.01$, twofold cutoff) by HBF clones versus LBF clones according to gene molecular function. $\mathbf{d}$ Real-time RT-PCR analysis of some upregulated genes (from microarray analysis by HBF clones versus LBF cones). The expression of each target gene was normalized to RG and presented as relative expression to RG. Data presented as mean (three different clones of both HBF and LBF clones) \pm SEM of at least three independent experiments $\left({ }^{*} p \leq 0.05,{ }^{* *} p \leq 0.01\right.$, between LBF versus HBF clones). PDGF platelet-derived growth factor, $R G$ reference genes

capacity, MACS-enriched PDGFR $\beta^{+}$cells from hBMSCTERT $^{- \text {Bone }}$ (Fig. 5a) were obtained and the PDGFR $\beta^{+}$ cells were examined for their response to PDGF isoforms in the transwell migration assay. Sorted PDGFR $\beta^{+}$ cells exhibited enhanced chemotactic migration toward different PDGF isoforms as compared with the PDGFR $\beta$ negative population (Fig. 5 b).

\section{Discussion}

In the present study, we demonstrate that a subpopulation of hBMSC with known ability to form bone in vivo exhibits enhanced ability to migrate in vitro and to home to bone fractures in vivo. In addition, we identified a molecular signature that defines this population and one surface marker, PDGFR $\beta$ (CD 140b), that can be employed for prospective isolation of the cells with enhanced migratory capacity from heterogeneous hBMSC cultures.

hBMSC are capable of multilineage differentiation into various mesoderm-type cells including osteoblastic cells [33], which is the basis for their use in cell-based therapies for bone tissue regeneration; for example, in repair of bone defects and nonhealed fractures [34-36]. However, cultured hBMSC represent a heterogeneous population with respect to differentiation capacity (so-called progenitor functions) as well as nonprogenitor functions. For example, not all hBMSC maintained under standard culture conditions are capable of bone formation [19]. 

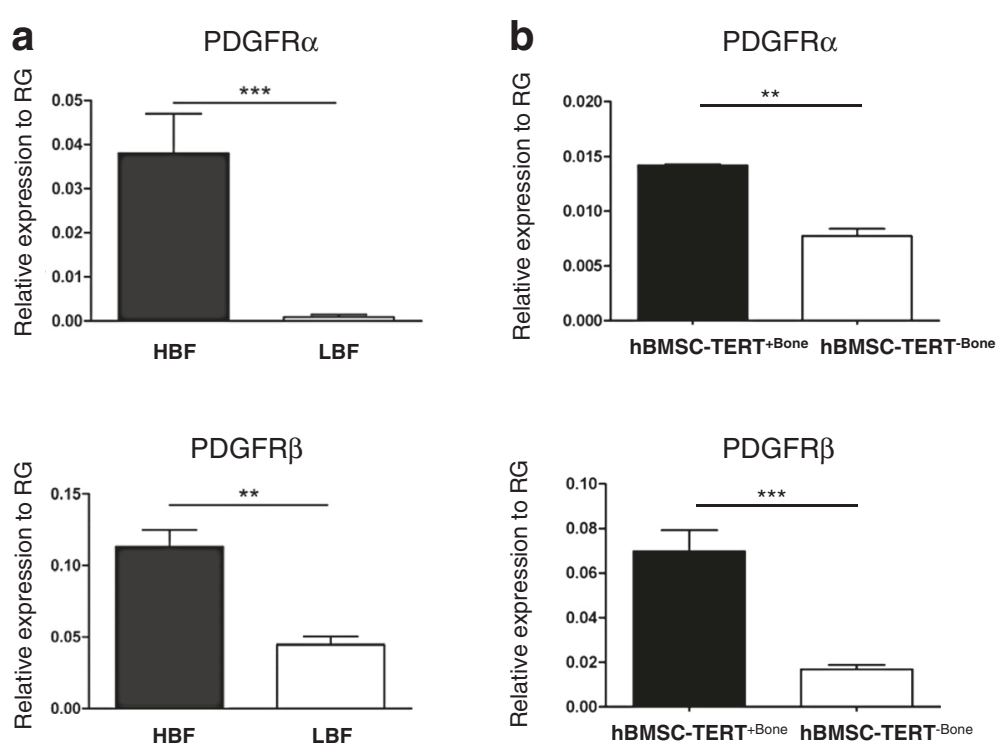

Fig. 3 PDGFRa/ $\beta$ expression in HBF versus LBF. a Real-time RT-PCR analysis of PDGFRa and PDGFRß expression by HBF versus LBF clones, and b hBMSC-TERT ${ }^{\text {Bone }}$ versus hBMSC-TERT ${ }^{\text {Bone }}$. Expression of each target gene was normalized to RG and presented as relative expression to RG. Data presented as mean (three different clones of each HBF and LBF clones) \pm SEM of at least three independent experiments $\left(^{*} p \leq 0.05\right.$,

$\left.{ }^{* *} p \leq 0.01,{ }^{* * *} p \leq 0.005\right)$. HBF high bone forming, hBMSC human bone marrow stromal stem cells, LBF low bone forming, PDGFR platelet-derived growth factor receptor, $R G$ reference genes

Similarly, when hBMSC are infused intravenously, only a small population of cells home to injured tissue [37]. The efficient use of hBMSC in therapy thus requires defining an ex vivo molecular phenotype predictive for the in vivo behavior [21]. In the present study, we have investigated the correlation between two characteristics: cellular migratory behavior and ability to form heterotopic bone, as well as homing capacity to bone fractures in vivo. For this purpose, we employed previously characterized hBMSC clones with various capacities for in vivo heterotopic bone formation. Our data suggest that in vivo heterotopic bone formation capacity is associated with enhanced in vivo migratory abilities to bone fractures.

By comparing the transcriptome profile of hBMSCTERT $^{+ \text {Bone }}$ and hBMSC-TERT ${ }^{- \text {Bone }}$ and clones with different heterotopic bone-forming capacities, we identified a molecular signature linking homing and in vivo bone formation potential. This molecular signature included expression of high levels of known genes important for cell migration and homing. Among these were chemokine (C-X-C motif) receptor 7 (CXCR7) and chemokine (C-X-C motif) ligand 12 (CXCL12) [38], extracellular matrix, and adhesion molecules (e.g., collagen, type XVI, alpha 1 (COL16A1) and vascular cell adhesion molecule 1 (VCAM-1)) [39].

We have demonstrated that hBMSC with boneforming capacity can home to bone fracture, suggesting that these migratory cells are recruited from the circulation under physiological conditions of bone formation and bone regeneration. However, the contribution of homed hBMSC to bone regeneration at bone fracture sites has been a contentious issue [40]. Some studies have demonstrated that circulating hBMSC can home and contribute to fracture healing [36, 41, 42]. Also, patients with recent fractures have a large number of circulating osteoprogenitor (i.e., hBMSC-like) cells in their peripheral circulation, providing circumstantial evidence of recruiting bone-forming cells to bone fracture sites [43]. On the other hand, some studies have demonstrated that the contribution of homed hBMSC to bone fracture healing is limited and that fracture healing is mediated by locally recruited cells possibly from periosteum or bone marrow [44, 45]. Our study suggests that there exists a population of hBMSC with enhanced bone-forming and migratory capacity. Further prospective studies are needed to quantitate the contribution of this cell population to fracture healing and bone regeneration.

Some of the molecules identified in the molecular signature defining high bone formation and migratory capacity do not seem to contribute to the migratory phenotype. For example, CXCR7 expression was highly upregulated in cells with HBF capacity, but we were unable to detect an increased ex vivo chemotactic migration toward its ligand SDF-1. It is possible that other noncanonical receptors are involved in regulating the migratory function of hBMSC. It is also plausible that hBMSC differ from leucocytes regarding the molecules employed for transendothelial migration. In support of this notion, we did not 


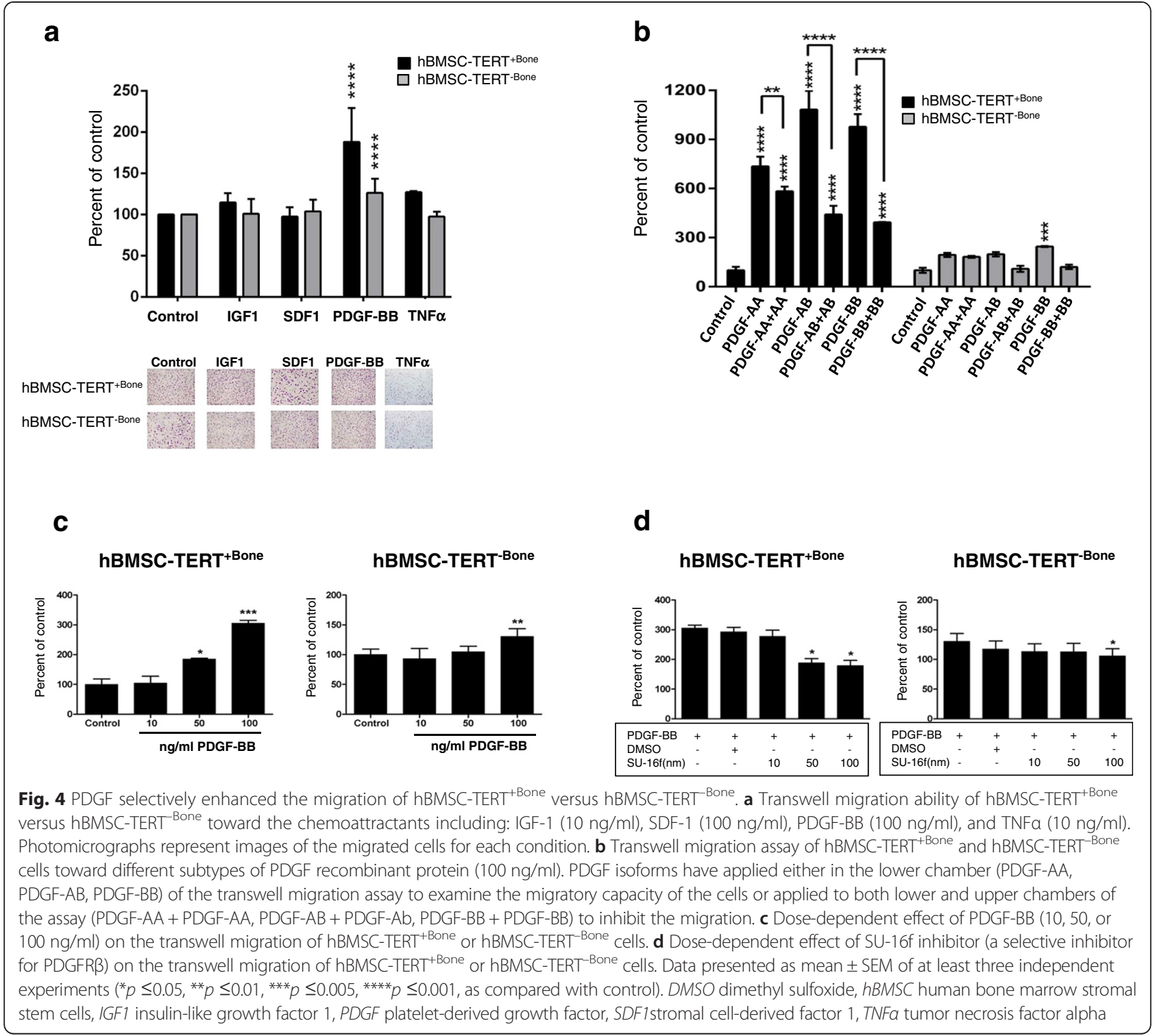

detect increased homing of hBMSC to bone fracture in vivo in hBMSC overexpressing CXCR4 (data not shown), a known factor enhancing leukocyte and HSC homing [46].

We identified high expression levels of PDGFR $\alpha$ and PDGFR $\beta$ to be associated with enhanced chemotactic migration of hBMSC toward PDGF isoforms. Therefore, PDGFR $\beta$ can be used as a possible marker to enrich for hBMSC with high ex vivo migratory capacity. PDGFs, via binding to their cognate receptors PDGFR $\alpha$ and PDGFR $\beta$, have been reported previously as potent chemoattractants for multiple cell types including hBMSC [47-50]. Our study corroborates and extends previous findings by showing the possible prospective isolation of hBMSC with enhanced migratory capacity based on PDGFR $\beta$ expression.
Our study has some limitations. First, we employed a telomerized cell line (hBMSC-TERT) and not primary hBMSC for isolating subpopulations of BMSC. hBMSCTERT has the advantage of having a stable phenotype during long-term culture and our extensive experience with hBMSC-TERT demonstrate that these cells maintain a phenotype similar to primary hBMSC in vitro and in vivo [24] and has comparable molecular signature to primary hBMSC [51]. While hMSC-TERT has been employed in a clinical trial as a vehicle for drug delivery [52], the cells are not suitable for clinical trials for bone regeneration due to their genetic modification and the risk of transformation. Future studies on the relevance of our findings to in vivo bone regeneration should thus be conducted using primary human cells in preclinical animal models [53]. Second, the identified PDGFR $\beta$ can 

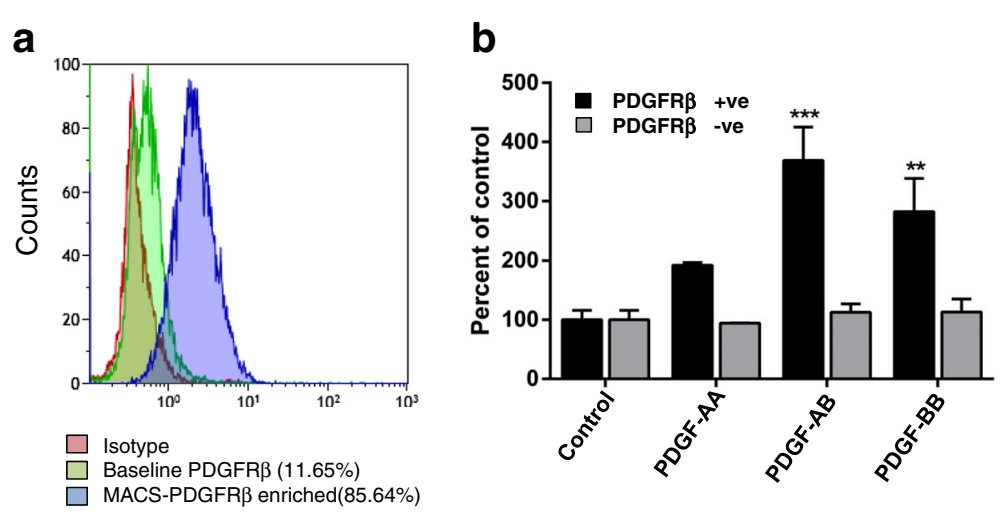

Fig. 5 PDGFR $\beta$ as a potential marker for enhancing hBMSC migration. a FACS analysis of PDGFR $\beta$ in hBMSC-TERT-Bone before and after enrichment for PDGFR $\beta^{+}$cells. $\mathbf{b}$ MACS PDGFR $\beta^{+}$-enriched cells from hBMSC-TERT ${ }^{- \text {-Bone }}$ were compared with PDGFR $\beta^{-}$cells for their migratory response toward different PDGF isoforms (PDGF-AA, PDGF-BB, or PDGF-AB) $(100 \mathrm{ng} / \mathrm{ml})$. Data presented as mean \pm SEM of at least three independent experiments $\left({ }^{*} p \leq 0.05,{ }^{* *} p \leq 0.01,{ }^{* *} p \leq 0.005\right.$, as compared with control). PDGFR platelet-derived growth factor receptor

be both a marker and functional protein contributing to enhance migration. Our studies do not distinguish between these two possibilities. Third, prospective isolation of PDGFR $\beta^{+}$cells from heterogeneous hBMSC cultures that can both home and contribute to fracture healing needs to be performed.

\section{Conclusion}

This study demonstrates that cultured hBMSC, in addition to cellular heterogeneity, exhibit functional heterogeneity and that bone formation and homing abilities are closely linked characteristics that can be defined by a common molecular signature. Further studies are needed to determine the role of PDGFR $\beta$ in hBMSC homing and to isolate hBMSC populations based on their molecular signature to be tested in preclinical animal models for enhancing fracture healing and bone regeneration.

\section{Additional file}

Additional file 1: Figure S1. Showing generation and differentiation of hBMSC-TERT-Luc cell lines, Table S1 presenting a list of primers used for RT-PCR, and Table S2 presenting genes upregulated by group 1 (hMSC-TERT ${ }^{+B o n e}$ and three HBF clones) over group 2 (hMSC-TERT ${ }^{-B o n e}$ and three LBF clones).(PDF $317 \mathrm{~kb}$ )

\section{Abbreviations}

BMSC: Bone marrow-derived stromal cells; BSA: Bovine serum albumin; DMSO: Dimethyl sulfoxide; EDTA: Ethylenediamine tetraacetic acid; FBS: Fetal bovine serum; FCS: Fetal calf serum; FDR: False discovery rate; FITC: Fluorescein isothiocyanate; HBF: High bone forming; hBMSC: Human bone marrow-derived stromal stem cells; HSC: Hematopoietic stem cell; IGF1: Insulin-like growth factor 1; LBF: Low bone forming; LG-DMEM: Low-glucose Dulbecco's minimal essential medium; MEM: Minimal essential medium; PBS: Phosphate-buffered saline; PDGF: Platelet-derived growth factor; PDGFR: Platelet-derived growth factor receptor; RG: Reference genes; ROI: Regions of interest; SDF1: Stromal cell derived factor 1; SEM: Standard error of the mean; TNFa: Tumor necrosis factor alpha.

\section{Competing interests}

The authors declare that they have no competing interests.

\section{Authors' contributions}

RKA and WZ carried out in vitro migration studies and in vivo homing experiments, analyzed data, and revised the manuscript. KHL and ND performed molecular genetics and in vivo studies, analyzed data, and revised the manuscript. KD, WW, and JA carried out and analyzed the microarray study and revised the manuscript. BMA performed the cytoskeletal study, contributed to the study design, and drafted and revised the manuscript. MK conceived of the study, and participated in the study design and revised the manuscript. All authors read and approved the manuscript.

\section{Acknowledgments}

This study was supported by a grant from the Danish Innovation fond ("Efficient Homing into Injured Tissues: Systemic Cell-based Therapy using Mesenchymal Stem Cells (MSC)", 09-067112), Odense University Hospital, Odense, Denmark. WZ has received a fellowship from the Saudi Ministry of Higher Education and support from the College of Medicine Research Center, Deanship of Scientific Research, King Saud University.

\section{Author details}

${ }^{1}$ Department of Endocrinology and Metabolism, University Hospital of Odense, Odense, Denmark. ${ }^{2}$ Stem Cell Unit, Department of Anatomy, College of Medicine, King Saud University, Riyadh, Saudi Arabia. ${ }^{3}$ Department of Vertebrate Genomics, Molecular Embryology and Aging Group, Max Planck Institute for Molecular Genetics, Berlin, Germany. ${ }^{4}$ Research and Regenerative Medicine, Faculty of Medicine, Heinrich Heine University, Duesseldorf, Germany. ${ }^{5}$ Faculty of Science, Helwan University, Cairo, Egypt. ${ }^{6}$ Danish Stem Cell Center (DanStem), Faculty of Health Sciences, University of Copenhagen, Copenhagen, Denmark.

Received: 5 June 2015 Revised: 2 September 2015

Accepted: 21 September 2015 Published online: 08 October 2015

\section{References}

1. Jafari A, Harkness L, Zaher W, Kassem M. Adult stromal (skeletal, mesenchymal) stem cells: advances towards clinical applications. In: Turksen K, editor. Adult stem cells. New York: Springer; 2014. p. 359-73.

2. Nejadnik H, Hui JH, Feng Choong EP, Tai BC, Lee EH. Autologous bone marrow-derived mesenchymal stem cells versus autologous chondrocyte implantation: an observational cohort study. Am J Sports Med. 2010;38:1110-6

3. Quarto R, Mastrogiacomo M, Cancedda R, Kutepov SM, Mukhachev V, Lavroukov A, et al. Repair of large bone defects with the use of autologous bone marrow stromal cells. N Engl J Med. 2001;344:385-6. 
4. Hernigou P, Poignard A, Beaujean F, Rouard H. Percutaneous autologous bone-marrow grafting for nonunions. Influence of the number and concentration of progenitor cells. J Bone Joint Surg Am. 2005;87:1430-7.

5. Yelda T, Berrin U, Murat S, Aytac O, Sevgi B, Yasemin S, et al. Intracoronary stem cell infusion in heart transplant candidates. Tohoku J Exp Med. 2007:213:113-20.

6. Suzuki K, Murtuza B, Suzuki N, Smolenski RT, Yacoub MH. Intracoronary infusion of skeletal myoblasts improves cardiac function in doxorubicin-induced heart failure. Circulation. 2001;104:1213-7.

7. Yang Q, Zhang J, Jiang J. Intracoronary transplantation of genetically modified mesenchymal stem cells, a novel method to close muscular ventricular septal defects. Med Hypotheses. 2011;77:505-7.

8. Chen SL, Fang WW, Ye F, Liu YH, Qian J, Shan SJ, et al. Effect on left ventricular function of intracoronary transplantation of autologous bone marrow mesenchymal stem cell in patients with acute myocardial infarction. Am J Cardiol. 2004;94:92-5.

9. Magnon C, Frenette PS. Hematopoietic stem cell trafficking. In: StemBook. Cambridge, MA: Harvard Stem Cell Institute; 2008.

10. Ji JF, He BP, Dheen ST, Tay SS. Interactions of chemokines and chemokine receptors mediate the migration of mesenchymal stem cells to the impaired site in the brain after hypoglossal nerve injury. Stem Cells. 2004;22:415-27.

11. Shi M, Li J, Liao L, Chen B, Li B, Chen L, et al. Regulation of CXCR4 expression in human mesenchymal stem cells by cytokine treatment: role in homing efficiency in NOD/SCID mice. Haematologica. 2007;92:897-904.

12. Devine SM, Bartholomew AM, Mahmud N, Nelson M, Patil S, Hardy W, et al. Mesenchymal stem cells are capable of homing to the bone marrow of non-human primates following systemic infusion. Exp Hematol. 2001;29:244-55.

13. Horwitz EM, Gordon PL, Koo WKK, Marx JC, Neel MD, McNall RY, et al. Isolated allogeneic bone marrow-derived mesenchymal cells engraft and stimulate growth in children with osteogenesis imperfecta: implications for cell therapy of bone. Proc Natl Acad Sci U S A. 2002;99:8932-7.

14. Yang X, Balakrishnan I, Torok-Storb B, Pillai MM. Marrow stromal cell infusion rescues hematopoiesis in lethally irradiated mice despite rapid clearance after infusion. Adv Hematol. 2012;2012:142530.

15. Lange C, Brunswig-Spickenheier B, Cappallo-Obermann H, Eggert K, Gehling UM, Rudolph C, et al. Radiation rescue: mesenchymal stromal cells protect from lethal irradiation. PLoS One. 2011;6, e14486.

16. Eggenhofer E, Benseler V, Kroemer A, Popp FC, Geissler EK, Schlitt HJ, et al. Mesenchymal stem cells are short-lived and do not migrate beyond the lungs after intravenous infusion. Front Immunol. 2012;3:297.

17. Schrepfer S, Deuse T, Reichenspurner H, Fischbein MP, Robbins RC, Pelletier MP. Stem cell transplantation: the lung barrier. Transplant Proc. 2007;39:573-6.

18. Karp JM, Leng Teo GS. Mesenchymal stem cell homing: the devil is in the details. Cell Stem Cell. 2009:4:206-16.

19. Kuznetsov SA, Krebsbach PH, Satomura K, Kerr J, Riminucci M, Benayahu D et al. Single-colony derived strains of human marrow stromal fibroblasts form bone after transplantation in vivo. J Bone Miner Res. 1997;12:1335-47.

20. Muraglia A, Cancedda R, Quarto R. Clonal mesenchymal progenitors from human bone marrow differentiate in vitro according to a hierarchical model. J Cell Sci. 2000;113:1161-6.

21. Larsen KH, Frederiksen CM, Burns JS, Abdallah BM, Kassem M. Identifying a molecular phenotype for bone marrow stromal cells with in vivo bone forming capacity. J Bone Miner Res. 2009;25:796.

22. Post S, Abdallah BM, Bentzon JF, Kassem M. Demonstration of the presence of independent pre-osteoblastic and pre-adipocytic cell populations in bone marrow-derived mesenchymal stem cells. Bone. 2008;43:32-9.

23. Simonsen JL, Rosada C, Serakinci N, Justesen J, Stenderup K, Rattan SI, et al. Telomerase expression extends the proliferative life-span and maintains the osteogenic potential of human bone marrow stromal cells. Nat Biotechnol. 2002;20:592-6.

24. Abdallah BM, Haack-Sorensen M, Burns JS, Elsnab B, Jakob F, Hokland P, et al. Maintenance of differentiation potential of human bone marrow mesenchymal stem cells immortalized by human telomerase reverse transcriptase gene despite [corrected] extensive proliferation. Biochem Biophys Res Commun. 2005:326:527-38.

25. Ambion. Illumina TotalPrep RNA Amplification Kit. www.ambion.com.

26. Illumina HumanRef-8 v3 Expression BeadChips. www.llumina.com.
27. Benjamini $Y$, Hochberg $Y$. Controlling the false discovery rate: a practical and powerful approach to multiple testing. J R Stat Soc Ser B (Stat Method) 1995:289-300

28. da Huang W, Sherman BT, Lempicki RA. Systematic and integrative analysis of large gene lists using DAVID bioinformatics resources. Nat Protoc. 2009;4:44-57.

29. Dennis Jr G, Sherman BT, Hosack DA, Yang J, Gao W, Lane HC, et al. DAVID: Database for Annotation, Visualization, and Integrated Discovery. Genome Biol. 2003:4:3.

30. http://david.abcc.ncifcrf.gov/home.jsp.

31. Bonnarens F, Einhorn TA. Production of a standard closed fracture in laboratory animal bone. J Orthop Res. 1984;2:97-101.

32. Parsons JT, Horwitz AR, Schwartz MA. Cell adhesion: integrating cytoskeletal dynamics and cellular tension. Nat Rev Mol Cell Biol. 2010;11:633-43.

33. Abdallah BM, Jafari A, Zaher W, Qiu W, Kassem M. Skeletal (stromal) stem cells: an update on intracellular signaling pathways controlling osteoblast differentiation. Bone 2014

34. Tseng SS, Lee MA, Reddi AH. Nonunions and the potential of stem cells in fracture-healing. J Bone Joint Surg Am. 2008;90:92-8.

35. Granero-Molto F, Weis JA, Miga MI, Landis B, Myers TJ, O'Rear L, et al. Regenerative effects of transplanted mesenchymal stem cells in fracture healing. Stem Cells. 2009;27:1887-98.

36. Devine MJ, Mierisch CM, Jang E, Anderson PC, Balian G. Transplanted bone marrow cells localize to fracture callus in a mouse model. J Orthop Res. 2002;20:1232-9.

37. Wynn RF, Hart CA, Corradi-Perini C, O'Neill L, Evans CA, Wraith JE, et al. A small proportion of mesenchymal stem cells strongly expresses functionally active CXCR4 receptor capable of promoting migration to bone marrow. Blood. 2004;104:2643-5.

38. Dar A, Kollet O, Lapidot T. Mutual, reciprocal SDF-1/CXCR4 interactions between hematopoietic and bone marrow stromal cells regulate human stem cell migration and development in NOD/SCID chimeric mice. Exp Hematol. 2006;34:967-75.

39. Aldridge V, Garg A, Davies N, Bartlett DC, Youster J, Beard H, et al. Human mesenchymal stem cells are recruited to injured liver in a beta1 integrin and CD44 dependent manner. Hepatology. 2012;56:1063.

40. Bielby $\mathrm{R}$, Jones $\mathrm{E}, \mathrm{McGonagle} \mathrm{D}$. The role of mesenchymal stem cells in maintenance and repair of bone. Injury. 2007;38:S26-32.

41. Shirley D, Marsh D, Jordan G, McQuaid S, Li G. Systemic recruitment of osteoblastic cells in fracture healing. J Orthop Res. 2005;23:1013-21.

42. Tu Q, Valverde P, Li S, Zhang J, Yang P, Chen J. Osterix overexpression in mesenchymal stem cells stimulates healing of critical-sized defects in murine calvarial bone. Tissue Eng. 2007;13:2431-40.

43. Eghbali-Fatourechi GZ, Lamsam J, Fraser D, Nagel D, Riggs BL, Khosla S. Circulating osteoblast-lineage cells in humans. N Engl J Med. 2005:352:1959-66.

44. Arnsdorf EJ, Jones LM, Carter DR, Jacobs CR. The periosteum as a cellular source for functional tissue engineering. Tissue Eng A. 2009;15:2637-42.

45. Einhorn TA. The cell and molecular biology of fracture healing. Clin Orthop Relat Res 1998;355 Suppl:S7-21.

46. Lapidot T, Kollet O. The essential roles of the chemokine SDF-1 and its receptor CXCR4 in human stem cell homing and repopulation of transplanted immune-deficient NOD/SCID and NOD/SCID/B2m(null) mice. Leukemia. 2002;16:1992-2003.

47. Facchiano A, De Marchis F, Turchetti E, Facchiano F, Guglielmi M, Denaro A, et al. The chemotactic and mitogenic effects of platelet-derived growth factor-BB on rat aorta smooth muscle cells are inhibited by basic fibroblast growth factor. J Cell Sci. 2000;113:2855-63.

48. Seppa H, Grotendorst G, Seppa S, Schiffmann E, Martin GR. Plateletderived growth factor in chemotactic for fibroblasts. J Cell Biol. 1982;92:584-8.

49. Ozaki Y, Nishimura M, Sekiya K, Suehiro F, Kanawa M, Nikawa H, et al. Comprehensive analysis of chemotactic factors for bone marrow mesenchymal stem cells. Stem Cells Dev. 2007;16:119-29.

50. Phipps MC, Xu Y, Bellis SL. Delivery of platelet-derived growth factor as a chemotactic factor for mesenchymal stem cells by bone-mimetic electrospun scaffolds. PLoS One. 2012;7:e40831.

51. Al-Nbaheen M, Vishnubalaji R, Ali D, Bouslimi A, Al-Jassir F, Megges M, et al. Human stromal (mesenchymal) stem cells from bone marrow, adipose 
tissue and skin exhibit differences in molecular phenotype and differentiation potential. Stem Cell Rev. 2012

52. http://www.biocompatibles.com/media/press-releases/first-ever-treatmentof-stroke-patient-with-stem-cell-therapy-product.

53. Serakinci N, Guldberg P, Burns JS, Abdallah B, Schrodder $H$, Jensen $T$, et al. Adult human mesenchymal stem cell as a target for neoplastic transformation. Oncogene. 2004;23:5095-8.

Submit your next manuscript to BioMed Central and take full advantage of:

- Convenient online submission

- Thorough peer review

- No space constraints or color figure charges

- Immediate publication on acceptance

- Inclusion in PubMed, CAS, Scopus and Google Scholar

- Research which is freely available for redistribution 